\title{
Relevant Cytokines in the B Cell Lymphoma Micro-Environment
}

\author{
Günter Krause ${ }^{1,2, * \mathbb{C}}$, Floyd Hassenrück ${ }^{1,2}$ (D) and Michael Hallek ${ }^{1,2}$ \\ 1 Department I of Internal Medicine, University of Cologne, Kerpener Str. 62, 50937 Köln, Germany; \\ floyd.hassenrueck@uk-koeln.de (F.H.); michael.hallek@uni-koeln.de (M.H.) \\ 2 Cologne Cluster of Excellence on Cellular Stress Responses in Aging-associated Diseases (CECAD Cologne), \\ Joseph-Stelzmann-Str. 26, 50931 Cologne, Germany \\ * Correspondence: guenter.krause@uk-koeln.de; Tel.: +49-221-478-84125; Fax: +49-221-478-84115
}

Received: 3 July 2020; Accepted: 2 September 2020; Published: 5 September 2020

check for updates

\begin{abstract}
Cytokines are soluble protein factors with importance in intercellular communication and, as such, play pivotal roles in the pathogenesis of B cell malignancies. Evidence from in vitro cultures permitted us to choose example cytokines that bind to different biochemical receptor types. Activated malignant B cells or stromal fibroblasts and macrophages prominently secrete the chemokines CCL3 or CXCL12 and CXCL13, respectively. Apart from helper T cells, various cell types of the B cell lymphoma microenvironment are capable of producing the cytokines IL-4, IL-6, IL-10 and TNF $\alpha$. Owing to its impact on the development of myeloid cells, CSF-1 is among important soluble factors in the B cell lymphoma microenvironment. Inhibitors of B cell receptor-associated kinases often act via the blockade of cytokine production, but also prevent cytokine effects, e.g., chemotaxis. Increments in blood levels in chronic lymphocytic leukemia patients compared to healthy donors and normalization upon treatment with ibrutinib can be explained by producing cell types and modulation of cytokine production observed in vitro.
\end{abstract}

Keywords: chronic lymphocytic leukemia; T cells; lymphoma-associated macrophages; chemokines; B cell receptor; B cell receptor-associated kinases; PI3K; BTK; idelalisib; ibrutinib

A recent review article about cytokines in chronic lymphocytic leukemia (CLL) [1] prompted us to provide an overview of the current understanding of the biological basis of cytokine production by various cell types and how this is reflected or not in the cytokine blood levels observed in CLL patients compared to healthy controls. For this purpose, we wish to outline the biological diversity of cytokines involved in B cell malignancies, the roles of selected cytokines in the micro-environmental dialogue, and how these roles may influence clinically observed blood levels of the respective cytokines.

\section{Biological Diversity of Cytokines}

Talking about intercellular communication by soluble protein factors in quite general terms, it is of advantage to stratify the involved cytokines according to relevant categories. While producing or affected cell types often are difficult to define and alterations of cytokine blood levels may be influenced by multiple factors, biochemical receptor types offer a systematic classification scheme. Apart from the ligands of the class named catalytic receptors (CatR) that include a family called cytokine receptors (CkR) as well as e.g., tumor necrosis factor receptors (TNFR) and receptor tyrosine kinases (RTK) [2], cytokines may also belong to other categories, for instance chemokines that bind to G-protein-coupled receptors (GPCR). The interleukin (IL) nomenclature system was a useful innovation four decades ago, but the concept of ILs is increasingly superseded by that of cytokines that also include cellular interactions of cell types beyond leukocytes. Many, but not all of the cytokines that are named IL bind to members of the CkR family, which commonly signal via the JAK/STAT pathway. However, 
this heterogeneous group also includes, for instance, IL-8 and IL-34 that, according to their receptors, belong to other cytokine subgroups, namely chemokines and growth factors, respectively. Using the full spectrum of candidate cytokines without restriction to so-called ILs, unlike a recent review article [1], we selected examples of cytokines with relevance in B cell malignancies based on in vitro experiments involving lymphoma and bystander cells. After examples of chemokines that are predominantly produced by activated tumor cells, stromal fibroblasts or macrophages, we discuss cytokines that can be secreted by $\mathrm{T}$ cells and other cell types $[3,4]$ and talk about myeloid bystander cells and the impact of colony stimulating factor 1 (CSF-1) on their development. Possible associations of cytokine production in the lymphoma microenvironment with corresponding clinically observed blood levels in disease versus healthy controls and upon treatment with inhibitors of $B$ cell receptor (BCR)-associated kinases (BAK) are examined in a systematic and quantitative manner.

\section{Chemokine Production by Activated Malignant B Cells}

The chemokine CC-motif ligands (CCL) 3 and 4 are produced by CLL cells in co-culture with so-called nurse-like cells and upon engagement of the B cell receptor (BCR) [5]. Inhibitors of BAK, namely idelalisib and ibrutinib, which target PI3K $\delta$ and BTK, respectively, block this chemokine secretion by CLL cells [6,7]. Ibrutinib at concentrations above $10 \mathrm{nM}$ inhibits the secretion of CCL3 and CCL4 by anti-IgM-stimulated Ramos. The C481S mutation in BTK rescues the chemokine secretion in the presence of up to $1 \mu \mathrm{M}$ ibrutinib [8].

CCL3 and CCL4 serve as chemo-attractants of T lymphocytes and monocytes and lead to infiltration of these cell types into bone marrow and lymph nodes $[9,10]$. Therefore, maintained cytokine production in the presence of ibrutinib owing to the C481S mutation suggests that CCL3 and CCL4 may shape a supportive lymphoma microenvironment and thus contribute to in vivo selection of malignant B cells that express mutant BTK [8].

In accordance with its production by activated lymphoma cells, CCL3 is one of the most prominent cytokines with increased blood levels in CLL patients compared to healthy controls and dominates the cluster analysis of a comprehensive cytokine panel [11]. In accordance with ibrutinib-sensitive cytokine production by activated lymphoma cells, the elevated blood levels of CCL3 and CCL4 in CLL patients show strong reduction upon ibrutinib treatment compared to other cytokines (Table 1) [12].

\section{The Homing Chemokines CXCL12 and CXCL13}

The chemokine CXC-motif ligand 12 (CXCL12), formerly named stromal cell-derived factor 1 (SDF1), represents one of the most prominent and first recognized examples of cytokine-mediated interactions of CLL and bystander cells in co-cultures $[13,14]$. Stromal fibroblasts and adherent cells that grow out from peripheral blood mononuclear cells constitutively secrete CXCL12, which supports the survival and localization of CLL cells in lymphoid tissues. Since differentiated THP-1 macrophages, which provide similar survival support to CLL cells as bone marrow-derived murine macrophages [15], do not secrete CXCL12 [16], it is not clear whether production of this chemokine can be unequivocally attributed to myeloid bystander cells. In contrast, production of CXCL13, also known as B cell-attracting chemokine 1 (BCA-1), is linked to $\mathrm{CD} 68^{+}$macrophages by immunocytochemistry [17]. Secretion of the predominantly macrophage-derived CXCL13 [18] in bone marrow aspirates from CLL patients is significantly decreased during treatment with ibrutinib [12].

Idelalisib and ibrutinib inhibit migration of CLL cells to the homing chemokines CXCL12 and CXCL13 [6,7]. This provides an explanation for the compartment shift from lymphoid tissues into blood that often occurs early during treatment with these drugs. Compared to healthy donors, the blood levels of CXCL12 or CXCL13 in CLL patients are decreased or increased, respectively [17,19], which may reflect predominant production of these homing chemokines by stromal fibroblasts or myeloid bystander cells (Table 1). Elevated CXCL13 levels in CLL patients normalize during ibrutinib treatment [20]. 
Table 1. Selected cytokines of the B cell lymphoma micro-environment and alterations of their plasma levels.

\begin{tabular}{|c|c|c|c|c|}
\hline \multirow[t]{2}{*}{ Cytokine } & \multirow{2}{*}{ Receptor Type ${ }^{1}$} & \multirow{2}{*}{ Producing Cell Type ${ }^{2}$} & \multicolumn{2}{|c|}{$\begin{array}{c}\text { Blood Levels in CLL Patients } \\
\text { (-Fold of Reference) }\end{array}$} \\
\hline & & & CLL vs. Healthy Controls & Ibrutinib vs. Untreated CLL \\
\hline CCL3 & $\begin{array}{l}\text { CCR1, CCR } \\
\text { GPCR }\end{array}$ & \multirow[t]{2}{*}{ act. B-L [5] } & $6.7, * * * *[11]$ & $0.1,{ }^{* * * *}[12]$ \\
\hline CCL4 & $\begin{array}{l}\text { CCR5, CCR } \\
\text { GPCR }\end{array}$ & & $1.7, * * * *[11]$ & $0.3^{* * * *}[12]$ \\
\hline CXCL12 & $\begin{array}{l}\text { CXCR4, CXCR } \\
\text { GPCR }\end{array}$ & stromal fibroblasts [13] & $0.5, * *[19]$ & n.d. \\
\hline CXCL13 & $\begin{array}{l}\text { CXCR5, CXCR } \\
\text { GPCR }\end{array}$ & mon. ph. [18] & $3.9, * * *[17]$ & $0.3^{* * *}[20]$ \\
\hline IL-4 & $\begin{array}{l}\text { Type I } C k R \\
\text { CatR }\end{array}$ & \multirow[t]{2}{*}{ CLL-enriched CD8 ${ }^{+}$subset [22] } & 1.6, n.s. $[11]$ & 0.6, n.s. [12] \\
\hline IL-6 & $\begin{array}{l}\text { Type I } C k R \\
\text { CatR }\end{array}$ & & $2.8, *[11]$ & 0.5, n.s. [12] \\
\hline IL-10 & $\begin{array}{l}\text { Type II CkR } \\
\text { CatR }\end{array}$ & $\begin{array}{l}\text { act. B-L [23] } \\
\text { M2 M }[24]\end{array}$ & $0.8^{* * * *}[11]$ & $0.4^{* * * *}[12]$ \\
\hline $\mathrm{TNF} \alpha$ & $\begin{array}{l}\text { TNFR } \\
\text { CatR }\end{array}$ & $\begin{array}{l}\text { mon. ph. [25] } \\
\text { M1 M } \theta[24] \\
\text { act. B-L [8] }\end{array}$ & $4.2, *[11]$ & $0.3, *[12]$ \\
\hline CSF-1 & $\begin{array}{l}\text { CSF1R, RTK } \\
\text { CatR }\end{array}$ & $\begin{array}{l}\text { adherent mon. ph. [25] } \\
\text { act. B-L [26] }\end{array}$ & $2.7, * * * *[27]$ & n.d. \\
\hline
\end{tabular}

Receptor classes are printed in bold, families in italics. ${ }^{2}$ Abbreviations: act. B-L: activated B cell lymphoma cells; mon. ph.: mononuclear phagocytes; M1 M $\theta$, M2 M $\theta$ : macrophages of

**: $p<0.01 ; *: p<0.05 ;$ n.s.: not significant; n.d.: no data available. 


\section{T Cell Cytokines}

In CLL patients, the dialogue with lymphoma cells creates an increased and skewed $\mathrm{T}$ cell compartment resulting in a state of immune suppression [28]. Owing to this shift in $\mathrm{T}$ cell subtype composition, culture supernatants of isolated phytohemagglutinin-activated $\mathrm{T}$ cells from CLL patients, but not from healthy donors, contain detectable levels of IL-4 [22]. According to enzyme-linked immunoassays, the supernatants of anti-CD3-activated $\mathrm{T}$ cells from healthy donors cultured in vitro contain the cytokines IL-6, IL-10 and tumor necrosis factor $\alpha$ (TNF $\alpha$ ), but not IL-4 [21]. The PI3K $\delta$ inhibitor idelalisib reduces the production of the detected T cell cytokines in a concentration-dependent manner [21]. Other cell types are also capable of producing these cytokines. For instance, adherence-primed mononuclear phagocytes after stimulation with lipopolysaccharide secrete TNF $\alpha$ [25] and CLL cells after stimulation with CD40 ligand the immunosuppressive cytokine IL-10 [23]. These two cytokines also serve to distinguish the inflammatory or immunosuppressive phenotypes of M1 or M2 polarized macrophages [24]. Treatment with ibrutinib strongly reduces the blood levels of these T cell cytokines in CLL patients, which are higher than in healthy controls apart from IL-10 (Table 1).

\section{Myeloid Bystander Cells}

A decisive role of the myeloid compartment in the pathogenesis of CLL is demonstrated in the first place by mouse models $[15,29,30]$, but also supported by in vitro studies. Colony stimulating factor 1 (CSF-1), also known as macrophage CSF, plays decisive roles in the development of macrophages including their survival, proliferation, chemotaxis and polarization to an immunosuppressive phenotype [31,32]. Predominant secretion of IL-10 compared to TNF $\alpha$ reflects the immunosuppressive M2 polarization of tumor-associated macrophages [24]. So-called nurse-like cells were likened to thymic nurse cells owing to morphological similarity in their first description [14]. These cells that efficiently support the survival of CLL cells are derived from blood monocytes [33] and called lymphoma-associated macrophages in B cell malignancies other than CLL [34].

CSF-1 can be produced and secreted by adhering phagocytes but also by mantle cell lymphoma (MCL) cells [25,26]. Ibrutinib abrogates CSF-1 and IL-10 production in MCL cells and consequently inhibits macrophage polarization. The combination of BTK and CSFR inhibition leads to mutually enhanced effects on co-cultures of MCL cells and lymphoma-associated macrophages [26]. CSF-1 shows comparatively strongly elevated blood levels in CLL patients compared to healthy donors [27].

\section{Conclusions}

Enhancing a recent review article published in this journal [1], the present discussion of paracrine interactions in the B cell lymphoma microenvironment emanates from evidence gained with in vitro cultures of different cell types. The chemokines CCL3 and CXCL12 represent contrasting examples of induced and constitutive production by tumor and bystander cells. The cytokines IL-4, IL-6, IL-10 and $\mathrm{TNF} \alpha$ are produced by T cells, but often also by activated lymphoma cells or macrophages. As an additional important cytokine in this context, we suggest the RTK ligand CSF-1 that is essential for the development of lymphoma-associated macrophages. Production and effects of many of these cytokines are subject to disturbance by inhibitors of BAK in B cell lymphoma cells and in different types of bystander cells. The roles assigned to these example cytokines in the micro-environmental dialogue partially explain the compiled alterations in the blood levels of the corresponding cytokines owing to CLL and their normalization upon treatment with the BTK inhibitor ibrutinib. Finally, our commentary may support informed judgement on the article by Allegra et al. [1].

Funding: This research received no external funding.

Conflicts of Interest: The authors declare no conflict of interest. 


\section{References}

1. Allegra, A.; Musolino, C.; Tonacci, A.; Pioggia, G.; Casciaro, M.; Gangemi, S. Clinico-biological implications of modified levels of cytokines in chronic lymphocytic leukemia: A possible therapeutic role. Cancers 2020, 12, 524. [CrossRef] [PubMed]

2. Alexander, S.P.; Fabbro, D.; Kelly, E.; Mathie, A.; A Peters, J.; Veale, E.L.; Armstrong, J.F.; Faccenda, E.; Harding, S.D.; Pawson, A.J.; et al. The concise guide to pharmacology 2019/20: Enzymes. Br. J. Pharmacol. 2019, 176, S297-S396. [CrossRef] [PubMed]

3. Hacken, E.T.; Burger, J.A. Microenvironment interactions and B-cell receptor signaling in Chronic Lymphocytic Leukemia: Implications for disease pathogenesis and treatment. Biochim. et Biophys. Acta (BBA) Bioenerg. 2015, 1863, 401-413. [CrossRef] [PubMed]

4. Nguyen, P.-H.; Niesen, E.; Hallek, M. New roles for B cell receptor associated kinases: When the B cell is not the target. Leukemia 2019, 33, 576-587. [CrossRef]

5. Burger, J.A.; Quiroga, M.P.; Hartmann, E.; Bürkle, A.; Wierda, W.G.; Keating, M.J.; Rosenwald, A. High-level expression of the T-cell chemokines CCL3 and CCL4 by chronic lymphocytic leukemia B cells in nurselike cell cocultures and after BCR stimulation. Blood 2009, 113, 3050-3058. [CrossRef] [PubMed]

6. Hoellenriegel, J.; Meadows, S.A.; Sivina, M.; Wierda, W.G.; Kantarjian, H.; Keating, M.J.; Giese, N.; O’Brien, S.; Yu, A.; Miller, L.L.; et al. The phosphoinositide 3'-kinase delta inhibitor, CAL-101, inhibits B-cell receptor signaling and chemokine networks in chronic lymphocytic leukemia. Blood 2011, 118, 3603-3612. [CrossRef] [PubMed]

7. Ponader, S.; Chen, S.-S.; Buggy, J.J.; Balakrishnan, K.; Gandhi, V.; Wierda, W.G.; Keating, M.J.; O’Brien, S.; Chiorazzi, N.; Burger, J.A. The Bruton tyrosine kinase inhibitor PCI-32765 thwarts chronic lymphocytic leukemia cell survival and tissue homing in vitro and in vivo. Blood 2012, 119, 1182-1189. [CrossRef]

8. Göckeritz, E.; Vondey, V.; Guastafierro, A.; Pizevska, M.; Hassenrück, F.; Neumann, L.; Hallek, M.; Krause, G. Establishing a chemical genetic link between Bruton tyrosine kinase activity in malignant $\mathrm{B}$ cells and cell functions involved in the micro-environmental dialogue. Br. J. Haematol. 2017, 178, 949-953. [CrossRef]

9. Zucchetto, A.; Tripodo, C.; Benedetti, D.; Deaglio, S.; Gaidano, G.; Del Poeta, G.; Gattei, V. Monocytes/macrophages but not $\mathrm{T}$ lymphocytes are the major targets of the CCL3/CCL4 chemokines produced by CD38(+)CD49d(+) chronic lymphocytic leukaemia cells. Br. J. Haematol. 2010, 150, 111-113. [CrossRef]

10. Hartmann, E.M.; Rudelius, M.; Burger, J.A.; Rosenwald, A. CCL3 chemokine expression by chronic lymphocytic leukemia cells orchestrates the composition of the microenvironment in lymph node infiltrates. Leuk. Lymphoma 2015, 57, 563-571. [CrossRef]

11. Yan, X.-J.; Dozmorov, I.; Li, W.; Yancopoulos, S.; Sison, C.; Centola, M.; Jain, P.; Allen, S.L.; Kolitz, J.E.; Rai, K.R.; et al. Identification of outcome-correlated cytokine clusters in chronic lymphocytic leukemia. Blood 2011, 118, 5201-5210. [CrossRef] [PubMed]

12. Niemann, C.U.; Herman, S.E.M.; Maric, I.; Gomez-Rodriguez, J.; Biancotto, A.; Chang, B.Y.; Martyr, S.; Stetler-Stevenson, M.; Yuan, C.M.; Calvo, K.R.; et al. Disruption of in vivo chronic lymphocytic leukemia tumor-microenvironment interactions by ibrutinib-findings from an investigator-initiated phase II study. Clin. Cancer Res. 2015, 22, 1572-1582. [CrossRef] [PubMed]

13. Burger, J.A.; Burger, M.; Kipps, T.J. Chronic lymphocytic leukemia B cells express functional CXCR4 chemokine receptors that mediate spontaneous migration beneath bone marrow stromal cells. Blood 1999, 94 , 3658-3667. [CrossRef] [PubMed]

14. Burger, J.A.; Tsukada, N.; Burger, M.; Zvaifler, N.J.; Dell'Aquila, M.; Kipps, T.J. Blood-derived nurse-like cells protect chronic lymphocytic leukemia B cells from spontaneous apoptosis through stromal cell-derived factor-1. Blood 2000, 96, 2655-2663. [CrossRef] [PubMed]

15. Nguyen, P.-H.; Fedorchenko, O.; Rosen, N.; Koch, M.; Barthel, R.; Winarski, T.; Florin, A.; Wunderlich, F.T.; Reinart, N.; Hallek, M. LYN kinase in the tumor microenvironment is essential for the progression of chronic lymphocytic leukemia. Cancer Cell 2016, 30, 610-622. [CrossRef]

16. Maxwell, P.J.; Neisen, J.; Messenger, J.; Waugh, D.J. Tumor-derived CXCL8 signaling augments stroma-derived CCL2-promoted proliferation and CXCL12-mediated invasion of PTEN-deficient prostate cancer cells. Oncotarget 2014, 5, 4895-4908. [CrossRef]

17. Bürkle, A.; Niedermeier, M.; Schmitt-Gräff, A.; Wierda, W.G.; Keating, M.J.; Burger, J.A. Overexpression of the CXCR5 chemokine receptor, and its ligand, CXCL13 in B-cell chronic lymphocytic leukemia. Blood 2007, 110, 3316-3325. [CrossRef] 
18. Carlsen, H.S.; Baekkevold, E.S.; Morton, H.C.; Haraldsen, G.; Brandtzaeg, P. Monocyte-like and mature macrophages produce CXCL13 (B cell-attracting chemokine 1) in inflammatory lesions with lymphoid neogenesis. Blood 2004, 104, 3021-3027. [CrossRef]

19. Barretina, J.; Juncà, J.; Llano, A.; Gutierrez, A.; Flores, A.; Blanco, J.; Clotet, B.; Esté, J.A. CXCR4 and SDF-1 expression in B-cell chronic lymphocytic leukemia and stage of the disease. Ann. Hematol. 2003, 82, 500-505. [CrossRef]

20. Burger, J.A.; Keating, M.J.; Wierda, W.G.; Hartmann, E.; Hoellenriegel, J.; Rosin, N.Y.; De Weerdt, I.; Jeyakumar, G.; Ferrajoli, A.; Cárdenas-Turanzas, M.; et al. Safety and activity of ibrutinib plus rituximab for patients with high-risk chronic lymphocytic leukaemia: A single-arm, phase 2 study. Lancet Oncol. 2014, 15, 1090-1099. [CrossRef]

21. Herman, S.E.; Gordon, A.L.; Wagner, A.J.; Heerema, N.A.; Zhao, W.; Flynn, J.M.; Jones, J.; Andritsos, L.; Puri, K.D.; Lannutti, B.J.; et al. Phosphatidylinositol 3-kinase-delta inhibitor CAL-101 shows promising preclinical activity in chronic lymphocytic leukemia by antagonizing intrinsic and extrinsic cellular survival signals. Blood 2010, 116, 2078-2088. [CrossRef] [PubMed]

22. De Totero, D.; Reato, G.; Mauro, F.R.; Cignetti, A.; Ferrini, S.; Guarini, A.; Gobbi, M.; Grossi, C.; Foa, R. IL4 production and increased CD30 expression by a unique CD8+ T-cell subset in B-cell chronic lymphocytic leukaemia. Br. J. Haematol. 1999, 104, 589-599. [CrossRef] [PubMed]

23. [DiLillo, D.J.; Weinberg, J.B.; Yoshizaki, A.; Horikawa, M.; Bryant, J.M.; Iwata, Y.; Matsushita, T.; Matta, K.M.; Chen, Y.; Venturi, G.M.; et al. Chronic lymphocytic leukemia and regulatory B cells share IL-10 competence and immunosuppressive function. Leukemia 2012, 27, 170-182. [CrossRef] [PubMed]

24. Mantovani, A.; Sozzani, S.; Locati, M.; Allavena, P.; Sica, A. Macrophage polarization: Tumor-associated macrophages as a paradigm for polarized M2 mononuclear phagocytes. Trends Immunol. 2002, 23, 549-555. [CrossRef]

25. Haskill, S.; Johnson, C.; Eierman, D.; Becker, S.; Warren, K. Adherence induces selective mRNA expression of monocyte mediators and proto-oncogenes. J. Immunol. 1988, 140, 1690-1694. [PubMed]

26. Papin, A.; Tessoulin, B.; Bellanger, C.; Moreau, A.; Le Bris, Y.; Maisonneuve, H.; Moreau, P.; Touzeau, C.; Amiot, M.; Pellat-Deceunynck, C.; et al. CSF1R and BTK inhibitions as novel strategies to disrupt the dialog between mantle cell lymphoma and macrophages. Leukemia 2019, 33, 2442-2453. [CrossRef] [PubMed]

27. Janowska-Wieczorek, A.; Belch, A.R.; Jacobs, A.; Bowen, D.; Padua, R.A.; Paietta, E.; Stanley, E.R. Increased circulating colony-stimulating factor-1 in patients with preleukemia, leukemia, and lymphoid malignancies. Blood 1991, 77, 1796-1803. [CrossRef]

28. Van Attekum, M.H.; Eldering, E.; Kater, A.P. Chronic lymphocytic leukemia cells are active participants in microenvironmental cross-talk. Haematology 2017, 102, 1469-1476. [CrossRef]

29. Galletti, G.; Scielzo, C.; Barbaglio, F.; Rodriguez, T.V.; Riba, M.; Lazarevic, D.; Cittaro, D.; Simonetti, G.; Ranghetti, P.; Scarfò, L.; et al. Targeting macrophages sensitizes chronic lymphocytic leukemia to apoptosis and inhibits disease progression. Cell Rep. 2016, 14, 1748-1760. [CrossRef]

30. Hanna, B.S.; McClanahan, F.; Yazdanparast, H.; Zaborsky, N.; Kalter, V.; Rößner, P.M.; Benner, A.; Dürr, C.; Egle, A.; Gribben, J.G.; et al. Depletion of CLL-associated patrolling monocytes and macrophages controls disease development and repairs immune dysfunction in vivo. Leukemia 2015, 30, 570-579. [CrossRef]

31. Pixley, F.; Stanley, E.R. CSF-1 regulation of the wandering macrophage: Complexity in action. Trends Cell Biol. 2004, 14, 628-638. [CrossRef] [PubMed]

32. Polk, A.; Lu, Y.; Wang, T.; Seymour, E.; Bailey, N.G.; Singer, J.W.; Boonstra, P.S.; Lim, M.S.; Malek, S.; Wilcox, R. Colony-stimulating factor-1 receptor is required for nurse-like cell survival in chronic lymphocytic leukemia. Clin. Cancer Res. 2016, 22, 6118-6128. [CrossRef] [PubMed]

33. Tsukada, N.; Burger, J.A.; Zvaifler, N.J.; Kipps, T.J. Distinctive features of "nurselike" cells that differentiate in the context of chronic lymphocytic leukemia. Blood 2002, 99, 1030-1037. [CrossRef] [PubMed]

34. Burger, J.A.; Gribben, J.G. The microenvironment in chronic lymphocytic leukemia (CLL) and other B cell malignancies: Insight into disease biology and new targeted therapies. Semin. Cancer Biol. 2014, 24, 71-81. [CrossRef]

(C) 2020 by the authors. Licensee MDPI, Basel, Switzerland. This article is an open access article distributed under the terms and conditions of the Creative Commons Attribution (CC BY) license (http://creativecommons.org/licenses/by/4.0/). 